\title{
管内の乱流伝熱の組織的構造*
}

\author{
菱田幹 雄**, 長 野 靖 尚** \\ 田川正人****, 宮川晴 光****

\section{Turbulent Heat Transfer Associated with Coherent Structures in Fully Developed Pipe Flow} \\ by Mikio HISHIDA, Yasutaka NAGANO, \\ Masato TAGAWA, and Harumitsu MIYAKAWA
}

\begin{abstract}
Turbulent heat flux and Reynolds stress fluctuations in fully developed pipe flow have been measured by employing the combined cold wire and V-shaped hot wire anemometry technique, and then conditionally sampled and averaged. Instantaneous turbulent heat transfer is strongly associated with and dominated by the coherent turbulent structures, and thus the inherent intermittency of turbulent heat transport process is the consequence of the intermittent coherent motion near the wall. Conditionally averaged patterns of velocity, temperature and relevant turbulent heat flux fluctuations are obtained by analyzing the amplitude, mean period and duration of coherent motions. These recognized patterns reveal how the turbulent heat transfer is affected by four distinct types of coherent motions originating in the wall region and extending through a greater part of the pipe section.
\end{abstract}

Key Words : Convective Heat Transfer, Turbulence, Pipe Flow, Coherent Structure, Turbulent Heat Flux, Conditional Sampling

\section{1. 緒}

壁面乱流における伝熱機構を解明するには，壁面の 底層近くの乱流熱流束の挙動およびそれとレイノルズ 応力との関連を知ることが非常に重要である(1). 底層 近傍は乱流の組織的な構造が最も支配的となる領域で あり ${ }^{(2)(3)}$, 乱流熱輸送にも類似の組織的構造が存在す ることが期待されるが，測定が困難なことも原因して 実験が少なく(4)〜(6)，その詳細についてはいまだにあ まり分かっていない.

本研究は壁面乱流の性格を左右している伝熱面近傍 の組織的な乱流構造と乱流熱輸送の関連を，条件付サ ンプリングと条件付平均を行い，実験的に調べたもの である.その結果, 得られた定量的な組織的構造の特 性値をもとにして，速度と温度の変動をレイノルズ応 力と乱流熱流束の変動と併せて条件付アンサンブル平 均し, 乱流伝熱の典型的なパターンを明らかにした。

\footnotetext{
*昭和 58 年 11 月 21 日 第 922 回講演会において講演，原 稿受付 昭和 58 年 5 月 9 日.

**正員, 名古屋工業大学（466 名古屋市昭和区御器所 町).

***准員, 名古屋工業大学.

**** 学生員, 名古屋工業大学大学院.
}



2. 記 号

$H ：$ 条件付サンプリングの敷居值

$r_{0}:$ 伝熱管の半径

$\bar{T}_{j}:$ 現象の平均周期

$\Delta \bar{T}_{j}$ : 現象の平均継続時間

$t:$ 温度乱れ

$\bar{U}_{c}:$ 管中心の流体速度

$u, v$ : 軸方向および壁面に垂直方向の速度乱れ

$u_{*}$ : 摩擦速度

$y:$ 管壁より半径方向への距離

$y^{+}$: 無次元距離 $=u_{*} y / \nu$

$\delta *$ : 排除厚さ

$\gamma_{j}:$ 現象の間欠係数

$\nu$ : 動粘性係数

$\tau, \tau^{\prime}:$ 時間

$\overline{()}$ : 全時間平均值

$\langle>$ : 条件付平均值

( )': 移動平均値加らの変動分

\section{3. 実験装置および実験方法}

実験装置は既報 ${ }^{(1)(5)}$ と同じもので, 内径 $45.68 \mathrm{~mm}$ の壁温一定 $\left(99.8^{\circ} \mathrm{C}\right)$ の伝熱管内の空気流で，伝熱管入 
ロにおけるレイノルズ数 $R_{e}\left(=2 r_{0} \bar{U}_{0} / \nu\right)=4 \times 10^{4}$ に ついて実験を行った，速度場と温度場はともに完全に 発達していて, 中心速度と温度は $\bar{U}_{c}=17.9 \mathrm{~m} / \mathrm{s}$ およ び $\bar{T}_{c}=43.2^{\circ} \mathrm{C}$ ，また排除厚さと運動量厚さ ${ }^{(5)}$ はそれ ぞれ $\delta^{*}=2.16 \mathrm{~mm}, \theta=1.23 \mathrm{~mm}$ である. 2 方向の 速度乱れ $u, v$ と温度乱れ $t$ は V-I 形熱線 ${ }^{(7)}$ に抵抗 線を組み合わせて ${ }^{(8)}$ 測定した。データはレコーダに集 録し，A-D変換して大形計算機(FACOM M-200)に より条件付サンプリングと条件付平均を行った.デー タのサンプリング周波数は $32 \mathrm{kHz}$ である.

\section{4. 実験結果およひその考察}

4.1 組織的檴造の乱流熱流束への㚚与 壁面乱 流を支配している組織的構造の流動形热は， $u, v$ 平 面の各象限に対して表 1 のように分類される(2). それ に対応する $u, t$ 平面と $v, t$ 平面の分類を同表に示し たが, 速度乱れと温度乱れの相互の相関係数が 1 とは ならないので(1)， $u, v$ 平面と他の平面との対応は近似 的である。そこで以下の条件付サンプリングにおいて は, $u, v$ 平面で分類した流動形態には添字 $i$ を。

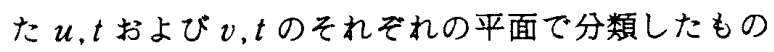
には添字 $j$ を付けて区別することにする。

$u, v$ 平面の四つの象限に分類された各現象が，乱 流熱流束の時間平均值に寄与する割合は, 前報(2)で 求めたレイノルズ応力への寄与率と同様にして次式で 求められる。

$$
\begin{aligned}
& \overline{\frac{(u t)_{i}}{\overline{u t}}}=\frac{1}{\overline{u t}} \lim _{T \rightarrow \infty} \frac{1}{T} \int_{0}^{T} u(\tau) t(\tau) I_{i}(\tau, H) d \tau, \\
& (i=1,2,3,4)
\end{aligned}
$$

ここで検出関数 $I_{i}(\tau, H)$ は

$$
I_{i}(\tau, H)=\left\{\begin{array}{c}
1: u, v \text { 平面の第 } i \text { 象限で } \\
|u v|>H \sqrt{u^{2}} \sqrt{v^{2}}, \\
0: \text { それ以外のとき }
\end{array}\right.
$$

$\overline{(v t)_{i}} / \overline{v t}$ についても前式と同様に表される.

敷居值 $H$ を変えたそれぞれの奇与率の結果を，図 1 に示した. 乱流の熱輸送はイジェクション $(i=2)$ と

\begin{tabular}{|c|c|c|c|c|c|c|}
\hline \multirow{2}{*}{$\frac{\text { Quadtont }}{1}$} & \multicolumn{2}{|c|}{ u.v Plane } & \multicolumn{2}{|c|}{ U.t Plane } & \multicolumn{2}{|c|}{ v.t Plane } \\
\hline & $\begin{array}{l}-(u v)_{1}<0 \\
u>0 . v>0\end{array}$ & $\begin{array}{c}\text { Outward } \\
\text { Interaction }\end{array}$ & $\begin{aligned}-(u t) & =0 \\
u>0, t & >0\end{aligned}$ & Interaction & $\begin{array}{l}(v t)_{1}>0 \\
v>0 . t>0\end{array}$ & Ejection \\
\hline 2 & $\begin{array}{l}-(U V)_{2}>0 \\
U<0 . v>0\end{array}$ & Ejection & $\begin{aligned}-(u t)_{2} & =0 \\
U<0 . t & =0\end{aligned}$ & $n$ & $\begin{array}{l}(v t)_{2}=0 \\
v<0 . t=0\end{array}$ & Ir \\
\hline 3 & $\begin{array}{r}-(u v)_{3}<0 \\
U<0 . v<0\end{array}$ & $\begin{array}{l}\text { Wallward } \\
\text { Interaction }\end{array}$ & $\begin{aligned}-(u t)_{3} & <0 \\
u<0 . t & =0\end{aligned}$ & on & $\begin{array}{l}(v t),>0 \\
v=0, t=0\end{array}$ & Sweep \\
\hline 4 & $\begin{array}{l}-(u v)_{t}>0 \\
u>0, v<0\end{array}$ & Sweep & $\begin{array}{r}-(u t) h_{h}>0 \\
u=0, t<0\end{array}$ & Swe & $\begin{array}{l}(v t)=0 \\
v>0, t=0\end{array}$ & Interaction \\
\hline
\end{tabular}
スイープ $(i=4)$ で代表される組織的構造により支配

表 1 各平面で分類された流動と熱輸送の形態
されていることが分かる，管中心部以外では $H>1.5$ 〔すなわち $|u v(\tau)|>1.5 \sqrt{u^{2}} \sqrt{v^{2}}$ ) の振幅の乱流運動に 基づく熱輸送はイジェクションとスイープ時のみであ り，インタアクション時の乱流伝熱は存在しない。ま た、イジェクションとスイープ時の図10乱流熱流束 の振幅分布がレイノルズ応力の場合 ${ }^{(2)}$ とよく似てい ることから、熱流束の変動振幅はレイノルス応力の変 動振幅 $H$ でほほ定まると見なすことができる。

次に組織的構造の各象限で造られる乱流熱流束の半 径方向の変化を, $H=0$ の場合について図 2 に示し た。断面内の広い簀囲にわたり、イジェクションによ り壁領域から高温流体が放出されて起こる熱輸送が最

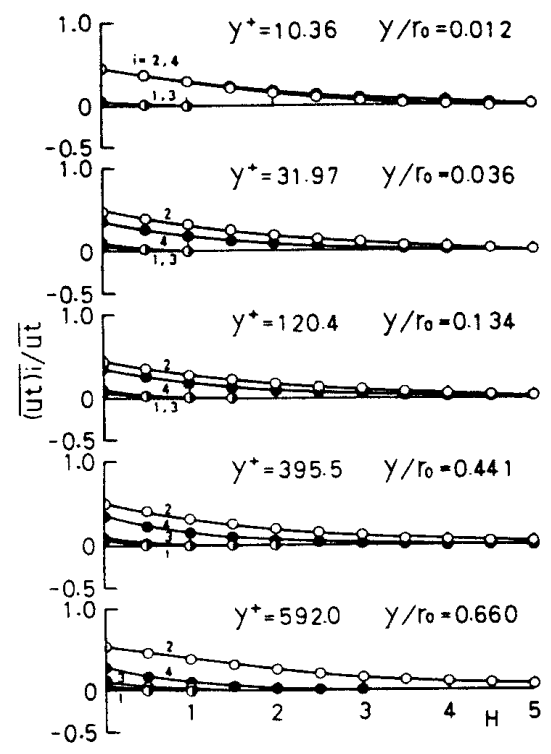

(a)



(b)

図 1 組織的棬造の全乱流熱流束への寄与 
も大きいが，伝熱面のごく近くでは乱流コア部の温度 の低い流体がスイープ運動によって伝熱面近傍へ運ば れることによる熱移動の割合が多くなっている．これ はレイノルス応力が壁面近傍ではスイープで，また壁 から離れた領域ではイジェクションにより最も多く生 成される(2)こととよく対応している，図 1，2加ら ジェクションとスイープによる組織的構造が乱流伝熱 の発生機構そのものであることが明らかとなった。

振幅の小さい速度変動 $(H<1.0)$ のインタアクショ ンは,レイノルズ応力の生成には負の寄与をした が(2)，軸方向乱流熱流束 $\overline{u t}$ に対しては正の寄与をし ている。これは温度乱れのスケールが速度のそれより も大きい(1255)ために，小振幅の乱流運動に $t$ は追従し ないことによるものであって, 後述の条件付平均して 求めた速度と温度の変動パターンによっても検証され ている.な打管中心にはあらゆる方向の伝熱面近傍か ら放出される高温度流体がイジェクション運動によっ

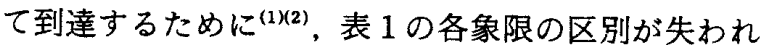
て熱輸送への寄与率はすべての象限で等しくなる。

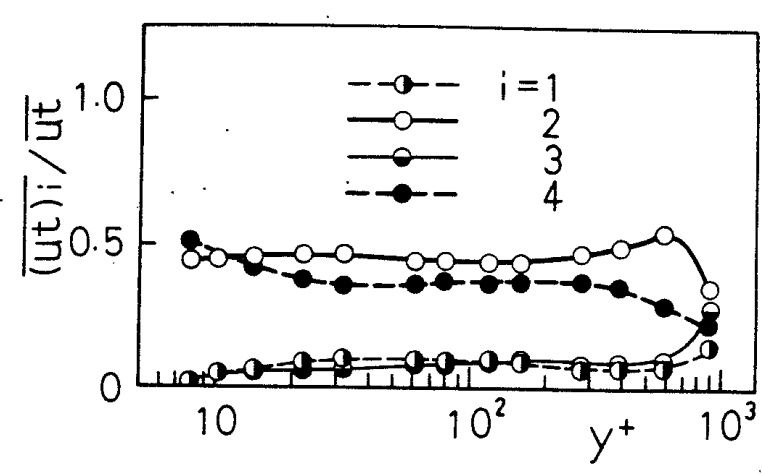

(a)

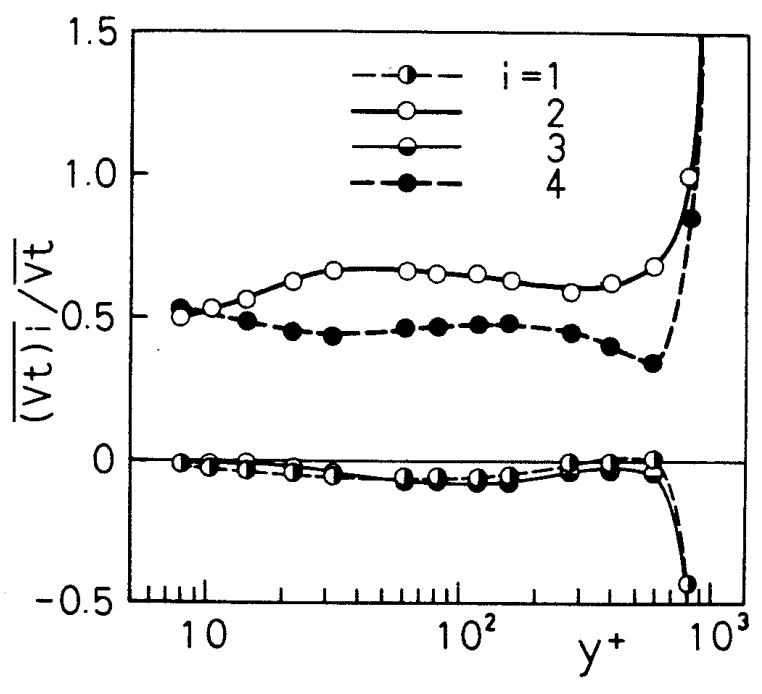

(b)

図 2 組織的構造の乱流運動に伴う乱流熱流束
$4 \cdot 2$ 組織的桠造の乱流エネルギおよび温度乱れ強 度への奇与 $u, v$ 平面で分類された各乱流運動 の, 乱流エネルギ $\overline{q^{2}}\left(=\overline{u^{2}}+\overline{v^{2}}+\overline{w^{2}}\right)$ と温度乱れの強 度 $\overline{t^{2}}$ への寄与率を式 (1) と同様にして求め, $H=0$ の場合の結果を図 3,4 にそれぞれ表した。接線方向の 速度乱れ $w$ は測定されていないが, $\overline{w^{2}} \cong\left(\overline{u^{2}}+\overline{v^{2}}\right) / 2$ と近似できる(1)ことから， $\overline{\left(q^{2}\right)_{i}} / \overline{q^{2}} \cong\left\{\overline{\left(u^{2}\right)_{i}}\right.$ $\left.+\overline{\left(v^{2}\right)_{i}}\right\} /\left(\overline{u^{2}}+\overline{v^{2}}\right)$ で乱流エネルギへの寄与率を評価 した。乱流エネルギと温度乱れ強度はともにイジェク ションとスイープ時に大部分が造られ，両運動による ものを合算すると全体のほほ $80 \%$ に達している.しか しこれはインタアクション時の速度と温度の変動振幅 が，他と比べて小さいことを示すものではない，イン タアクションの瞬時の振幅はイジェクションとスイー プに匹敵する大きさであり ${ }^{(2)}, \overline{q^{2}}$ と $\overline{t^{2}}$ への奇与が小 さいのは後述するようにその現象の継続時間が短いた めである. 管中心部ではすべての象限で $\overline{\left(q^{2}\right)_{i}} / \overline{q^{2}} \cong$ $\overline{\left(t^{2}\right)_{i}} / \overline{t^{2}} \cong 0.25$ となり，壁領域で見られた顐著な組織 的構造は失われ，速度と温度の乱机は一様になる。

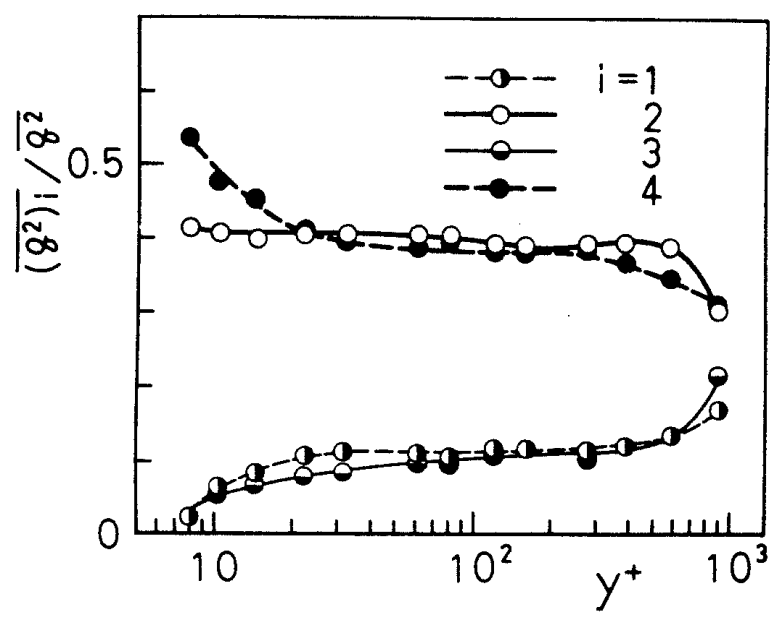

図 3 組織的構造の乱流エネルギへの寄与

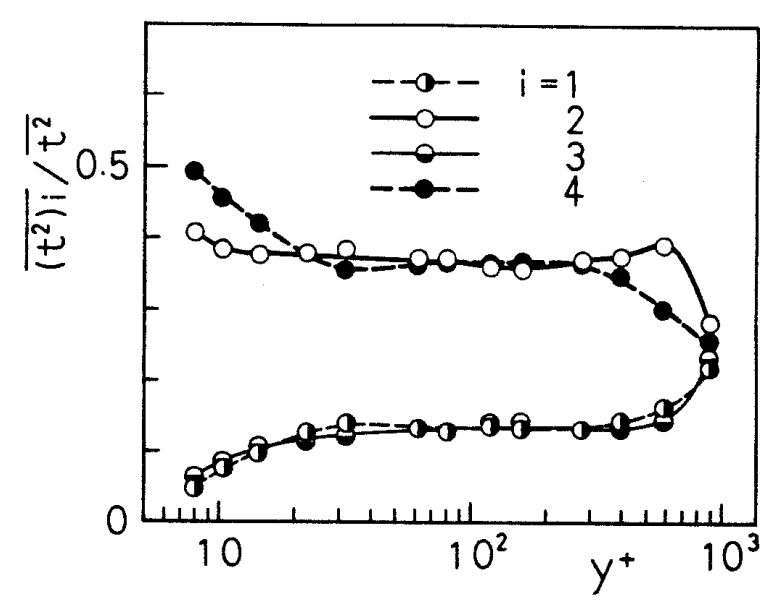

図 4 組織的構造の温度乱れ強度への寄与 
$4 \cdot 3$ 組織的構造の間欠係数，周期およひ継続時間 乱流熱流束の変動が間欠的であることは既報(1)で述 べたが，前述の結果からこれは組織的構造の間欠性に よるものと考えられる。そこでこの間欠性を定量的に 調べるために，表 1 の $u, v と u, t$ および $v, t$ の各 平面で四つの象限に分類された各現象の間欠係数 $\gamma_{j}$, 平均周期 $\bar{T}_{j}$ ，および平均継続時間 $\Delta \bar{T}_{j}$ を既報 ${ }^{(2)}$ と同 様の方法で求め，お互いの関連を調べた。教居值 $H=$ 0 の場合の， $v, t$ 平面における間欠係数の管断面内 の分布を, 図 5 に示した。イジェクションとスイープ 運動に対応する $j=1,3$ の間欠係数は, インタアクシ ヨンに相当するものの約 2 倍の值となっていて，組織 的構造を支配しているイジェクションとスイープの出 現頻度が高いことが分かる。また，イジェクションに 対応する現象の間欠係数は $30<y^{+}<600$ の管断面の 広い範囲で $\left(\gamma_{1}\right)_{v t} \simeq 0.32$ でほほ一定であるが，この値 は $u, v$ 平面から求まる速度場の組織的構造の間欠係 数 ${ }^{(2)}$ とよく一致している.

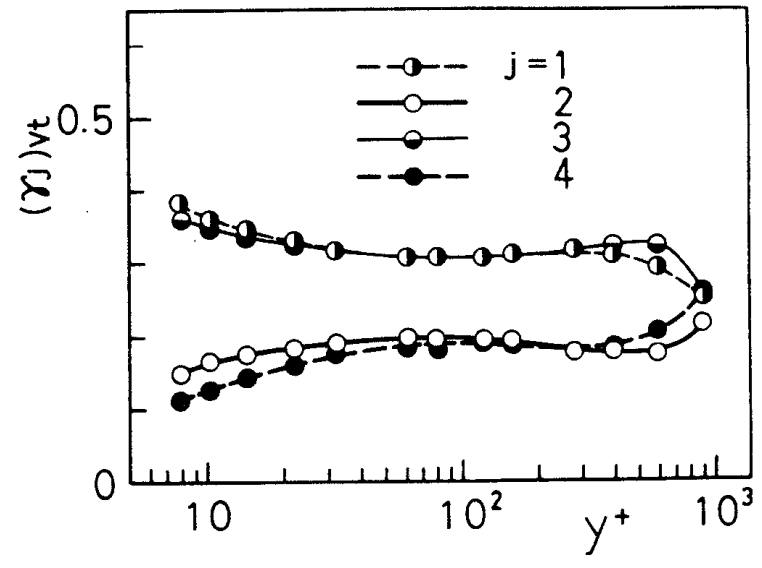

図 5 組織的構造の間欠係数

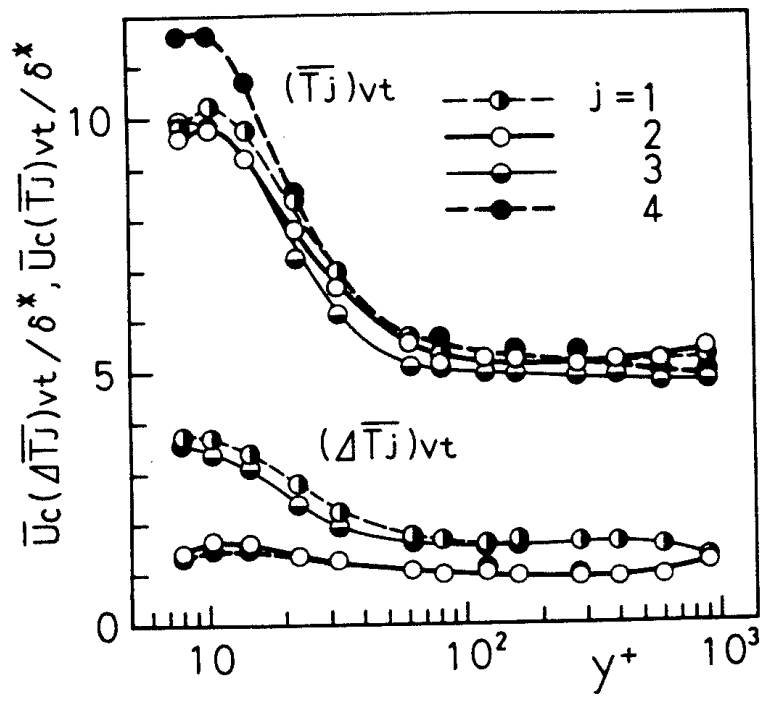

図 6 組織的構造の周期および継続時間 $v, t$ 平面上のそれそれの現象の平均周期 $\bar{T}_{j}$ およ び平均継続時間 $\Delta \bar{T}_{j}$ を図 6 に示した.これは $H=0 の$ 場合の結果であり，平均周期は大振幅変動で定まるバ 一スト周期より短いが(2), 大部分の乱流伝熱が組織的 な構造により発生することは裹付けされている。すな わ方,

（1） $v ， t$ 平面上の各象限を支配している運動の 周期は，どの象限でも同じである.

（2）各現象の継続時間は定まっていて，インタア クションの継続時間はイジェクションとスイープのそ れのほほ $1 / 2$ である。

（3）これらの値は速度場の組織的構造の特性值と ほほ一致している。

以上のことから，乱流熱輸送現象の間欠性は，速度 場の組織的構造の間欠性に直接起因しているものと見 なすことができる.

4.4 乱流熱輸送の組織的檴造の平均的パターン 4 ・3 節までの知見から乱流伝熱の組織的構造の輪郭は ほほ明らかとなったので，次にこれらを基にして，組 織的構造に伴う速度と温度の乱れおよび乱流熱流束の 変動の典型的なパターンを求めてみる。大きな変動に 埋もれている特定のパターンを認識するには，乱流諸 量 $Q(\tau)$ の短時間平均值 (移動平均値) $\tilde{Q}(\tau)$ の周りの 変動の様子を調べるのが最も効果的である ${ }^{(9 \times 10)}$. 区間 $T$ の移動平均 $\tilde{Q}(\tau)$ は次式で表される.

$$
\tilde{Q}(\tau)=\frac{1}{T} \int_{\tau-T / 2}^{\tau+T / 2} Q\left(\tau^{\prime}\right) d \tau^{\prime}
$$

積分区間 $T$ は, 前述の組織的構造の間欠性を表す特 性值に影響をおよぽさない範囲で、できるかぎり短い ほうがパターン認識の精度は向上する，組織的構造の 特性值が，区間 $T$ により変化する様子の一例を図 7 に示した.本研究では $T=51.9 \delta^{*} / \bar{U}_{c}$ としたが，組織 的構造の平均周期，平均継続時間などは $4 \cdot 3$ 節で求め たものとよく一致していることを確認した。

乱流熱流束の変動の平均的なパターンを求める試み

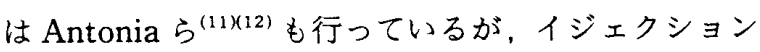

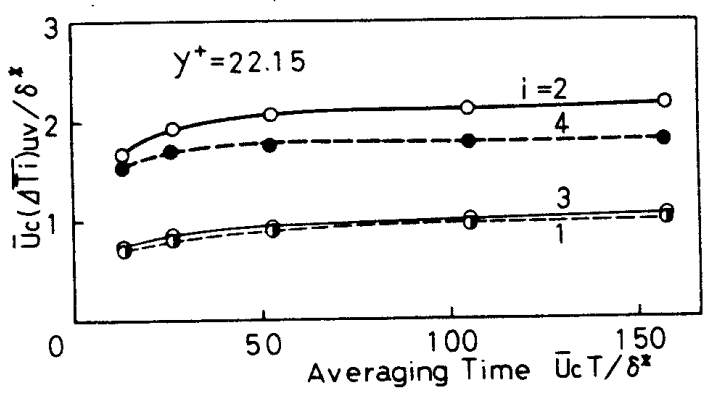

図 7 移動平均に基づく継続時間 
からスイープに移行する間のごく短時間の現象しか把 握されていない. 本研究では, 表 1 の $u, v$ 平面で分 類された組織的構造により発生する乱流伝熱を調べる ために，次の検出関数を用いた。

$$
I_{i}(\tau, H)=\left\{\begin{array}{c}
1: u^{\prime}, v^{\prime} \text { 平面の第 } i \text { 象限で } \\
\left|u^{\prime} v^{\prime}\right|>H \sqrt{u^{\prime 2}} \sqrt{v^{\prime 2}}, \\
0: \text { それ以外のとき }
\end{array}\right.
$$

ここで $u^{\prime}, v^{\prime}$ は $u, v$ の移動平均値からの変動分で ある.Tが十分大きい時には式(4)は式(2)に一致す る. 乱流諸量の変動分 $Q^{\prime}(\tau)$, 式 $(4)$ を用いた条件 付平均 $\left\langle Q^{\prime}(\tau)\right\rangle$ \&, 次式により求められる.

$$
\left\langle Q^{\prime}(\tau)\right\rangle=\frac{1}{N} \sum_{n=1}^{N} Q^{\prime}\left(\frac{\Delta T_{i}}{\overline{\Delta T_{i}}} \tau+\tau_{n}^{\prime}\right)
$$

ここで $N$ は第 $i$ 象限の現象の起きた回数, $\tau_{n}^{\prime}$ は第 $i$ 象限の現象の開始時刻， $\tau$ は $\tau_{n}^{\prime}$ からの経過時刻, $\Delta T_{i}$ は各回ごとの第 $i$ 象限の現象の継続時間, $\overline{\Delta T_{i}}$ は同継続時間の全時間平均値をそれぞれ表す。

条件付平均をした現象の典形的なパターンを図 8 に 表した。この図は $H=0$ の場合であって，小振幅から 大振幅に至る全現象の影響が平均的に含まれている。 またそれそれの変動値は, その実効值で無次元化した 值で示されている. $y^{+}=10.36$ 〔図 8 (a)]の伝熱面の ごく近傍では, 現象は $u, v$ 平面で $4 \rightarrow 3 \rightarrow 2 \rightarrow 1$ 象限 の順序で発生している。〈u'〉にると，イジェクショ ンによる緩慢な減速に続いて急激な加速をもたらすス イープが発生しているが,これが典型的なバースティ

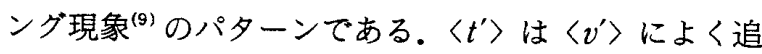
従し，〈政〉に対しては幾分遅れていることが分かる。

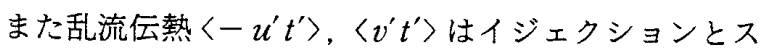
イープで同程度に発生している.このパターンの現れ る確率は約 $63 \%$ \%゙あったが，4・3節までに示した定 量的な関係はこの平均的パターンによく対応している ことが分かる。

壁から離れた領域になると，平均的パターンの様子 は異なってくる.図 8 ( b ) に $y^{+}=395.5$ のパターンを 示したが, 同図の (i ) は $4 \rightarrow 1 \rightarrow 2 \rightarrow 3$ 象限の順序で現 象が発生している場合，また（ii）は $4 \rightarrow 3 \rightarrow 2 \rightarrow 1$ 象限 の順序で現象が発生している場合である.この $y^{+}$の 位置では，変動のほとんどはパターン (i ) と (ii)で占 められるが，その出現の確率はパターン( i )が(ii)よ りも数\%大きい程度でほとんど変わらない.パターン (i)と（ii）の場合を比較すると，レイノルズ応力 く一 $\left.u^{\prime} v^{\prime}\right\rangle$ 発生については両者の間に大きな違いはな いが, 乱流熱流束の発生機構には大きな差異がある. すなうち,パターン（i ）では, スイープ運動により多
量の熱輸送が発生するが，イジェクション時には熱の 輸送は非常に少ない.また。〈ー $\left.u^{\prime} t^{\prime}\right\rangle$ はインタアクシ ヨン時にも熱輸送があることを示している(図 1，2). 一方, パターン(ii)の場合はイジェクション時に多量 の熱輸送が生じている。この時の伝熱量は，パターン ( i )でスイープ運動により運ばれるものより多いこと がわかる，その結果、時間平均した乱流熱輸送は，図
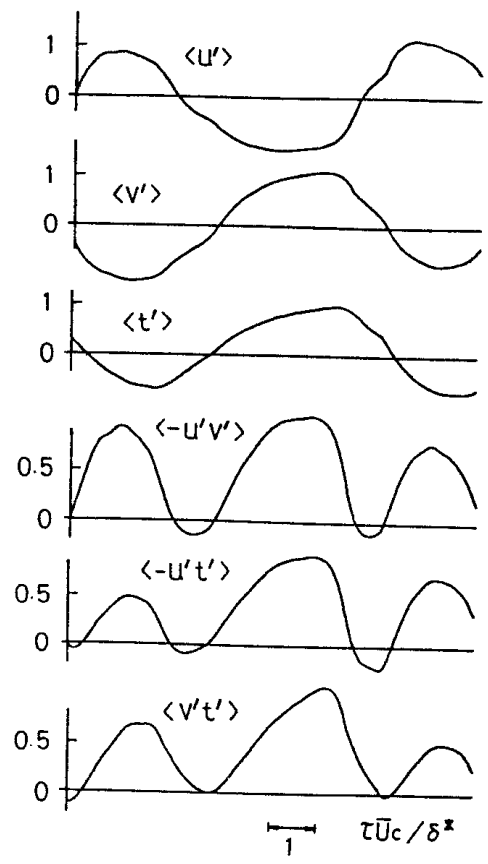

(a) $y^{+}=10.36$
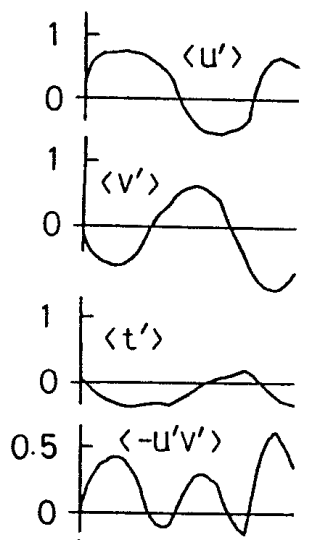



(i)
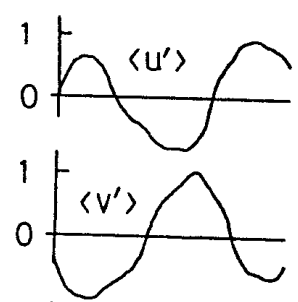

$1\left\langle t^{\prime}\right\rangle$


(ii) (b) $y^{+}=395.5$

図 8 組織的構造の典型的なパターン $(H=0)$ 

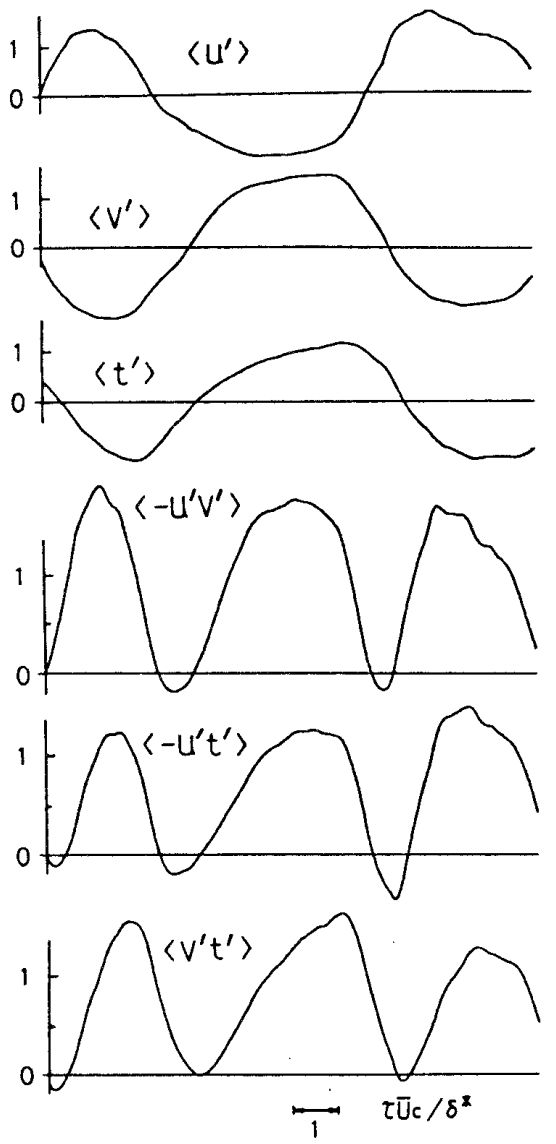

図 9 組織的構造のパターン $\left(y^{+}=10.36, H=1.0\right)$

2 で示したようにイジェクション時に発生する量がス イープ時におけるものよりも少し大きくなる. ChenBlackwelder ${ }^{(13)}$ 報告しているが, 速度の変動に対 して温度の変動には遅れが生じている.図 8 にると, この遅れはスイープよりもイジェクションの場合のほ うが大きい.

式(4)のイジェクションとスイープに対する敷居值 $H$ を変え, この乱流運動の前後に現れるインタアク ションを考慮した条件付平均の一例を, 図 9 に示し た.これは図8（a)に対応するパターンで $H=1.0$ の 結果である. 明らかに $H=0$ の場合よりも平均周期は 長くなり，イジェクションとスイープの平均継続時間 も長くなっているが，インタアクションの継続時間は 逆に短くなっている. 更にインタアクション時のレイ ノルズ応力と乱流熱流束の值は，イジェクションとス イープ運動によるものと比較して無視できる程度であ る.しかし、イジェクションとスイープの前後に現れ るインタアクションは, $\left\langle u^{\prime}\right\rangle,\left\langle v^{\prime}\right\rangle お よ ひ ゙\left\langle t^{\prime}\right\rangle$ の 振幅が大きく, 組織的構造の乱流運動のパターンとし ては重要で, 無視することはできない。

\section{5. 結喜}

条件付サンプリングと条件付平均を行うことによ り，管内乱流の熱輸送と組織的乱流構造との関係を調 ベた。 パターン認識法を用いることにより，乱流伝熱 の基本的な性質が明らかとなった，得られた結果は以 下のように要約される。

（1）乱流伝熱の間欠性は, 乱流の組織的構造の間 欠性によるものであり，これらの平均周期，平均継続 時間および間欠係数を明らかにした。

（2）乱流の熱輸送は，管断面の広い範囲て，イジ エクション運動により高温流体が壁領域から放出され ることにより発生するものが最も多い。

（3）伝熱面へ近づくに従って，スイープ運動によ り乱流コア部の低温流体が運ばれてくることによる熱 移動が多くなる。

（4）組織的構造を支配している乱流運動が発生し てから，それに伴う乱流伝熱が発生するまでには少し の遅れが生ずる，その結果，インタアクション時にも 熱輸送が発生する場合がある。

（5）乱流伝熱の組織的構造の典型的なパターンを 明らかにした，伝熱面近傍のパターンはほほ一義的に 定まるが，壁から離れた領域では二つの異なったパタ ーンが同程度の頻度で現れる。

（6）大振幅の流動に伴う乱流伝熱は，イジェクシ ヨンとスイープ運動による。これはインタアクション の継続時間が短くなるからであり, 速度と温度の変動 振幅はインタアクション時でも小さくはない.

\section{文献}

（1）菱田・ほ加2 名，機講論，No. 830-3 (昭 58-3)，102.

（2）菱田・長野，機論，47-413，B (昭 56)，50.

(3) Hirata, M., ほか3 名. Proc. 7th Int. Heat Transfer Conf., 1 (1982), 31.

(4) Perry, A.E. and Hoffmann, P. H., J. Fluid Mech, 772 (1976), 355.

（5）菱田・ほか 2 名，機論，44-377（昭 53），126。

（6）入谷・ほか 2 名。機論，48-435，B(昭 57)，2284。

（7）菱田・ほか 3 名，機論，46-408，B（昭 55）， 1467,

（8）菱田・ほ加 2 名，機論，43-365（昭 52）, 225.

(9) Wallace, J. M., ほか2名, J. Fluid Mech., 83-4(1977), 673.

(10) Blackwelder, R. F. and Kaplan, R. E., J. Fluid Mech., 76-1 (1976), 89.

(11) Antonia, R. A., ほか 3 名, J. Fluid Mech., 121(1982), 123.

(12) Subramanian, C. S., ほか 3 名. J. Fluid Mech., 123 (1982), 335.

(13) Chen, C.-H. P. and Blackwelder, R. F., J. Fluid Mech., 89-1 (1978), 1. 